\title{
Giant Cell Carcinoma
}

National Cancer Institute

\section{Source}

National Cancer Institute. Giant Cell Carcinoma. NCI Thesaurus. Code C3779.

A malignant epithelial neoplasm composed of giant, pleomorphic cells. 